\title{
Cladistics
}

\section{Evolution on a shaky piece of Gondwana: is local endemism recent in New Caledonia?}

\author{
Jérôme Murienne $^{\mathrm{a}}$, Philippe Grandcolas ${ }^{\mathrm{a}, *}$, Maria Dolors Piulachs ${ }^{\mathrm{b}}$, Xavier Bellés ${ }^{\mathrm{b}}$, \\ Cyrille D'Haese $^{\mathrm{a}}$, Frédéric Legendre ${ }^{\mathrm{a}}$, Roseli Pellens ${ }^{\mathrm{a}}$ and Eric Guilbert ${ }^{\mathrm{a}}$
}

${ }^{a}$ UMR 5202 CNRS, Département Systématique et Évolution, case 50, Muséum national d'Histoire naturelle, 45, rue Buffon, 75005 Paris, France;

${ }^{b}$ Department of Physiology and Molecular Biodiversity, Institut de Biologia Molecular, de Barcelona (CSIC), Jordi Girona 18, 0834 Barcelona, Spain

Accepted 5 November 2004

\begin{abstract}
New Caledonia is well known as a hot spot of biodiversity whose origin as a land mass can be traced back to the Gondwanan supercontinent. The local flora and fauna, in addition to being remarkably rich and endemic, comprise many supposedly relictual groups. Does the New Caledonian biota date back to Gondwanan times, building up its richness and endemism over $100 \mathrm{Myr}$ or does it result from recent diversifications after Tertiary geological catastrophic events? Here we use a molecular phylogenetic approach to answer this question with the study of the Neocaledonian cockroach genus Angustonicus belonging to the subfamily Tryonicinae from Australia and New Caledonia. Both geological and molecular dating show that the diversification of this group is less than two million years old, whatever the date of its origin itself. This dating is not consistent with hypotheses of Gondwanan richness and endemism in New Caledonian biota. In other terms, local richness and endemism at the specific level are not necessarily related to an old Gondwanan origin of the Neocaledonian groups.
\end{abstract}

(c) The Willi Hennig Society 2005.

Many evolutionary studies have focused on large and isolated oceanic islands, which are remarkable places to study colonization and speciation (Gillespie and Roderick, 2002). Among these islands, New Caledonia has until now received much less attention than other islands, either recent like Hawaii (Wagner and Funk, 1995; Fleischer et al., 1998) and Galapagos (Grant, 1986), or ancient like New Zealand (Daugherty et al., 1993; Cooper and Cooper, 1995).

New Caledonia is, however, well known as a hot spot of biodiversity (Myers et al., 2000) with outstanding levels of specific richness and endemism (Chazeau, 1993; Morat, 1993; Najt and Grandcolas, 2002). The flora is especially famous for harboring unique relictual taxa (Lowry, 1998; Parkinson et al., 1999) and this land mass is often described as a piece of Gondwana with relict tropical rainforest which has disappeared from almost

\footnotetext{
*Corresponding author. E-mail address: pg@mnhn.fr

everywhere else because of climatic change (Raven, 1979; Morat et al., 1986; Cooper and Millener, 1993).

In spite of its relictual characterization, the paleogeographic and geological history of New Caledonia is well-known to have been especially shaky since the Cretaceous Period, with a total submersion in the Paleocene, ophiolitic obduction in the Eocene, and Pliocene orogenesis (Paris, 1981; Brothers and Lillie, 1988; Cluzel et al., 2001; Lee et al., 2001). The relictual nature of the local biodiversity has also been hypothesized to be related to some of the oldest geological events, as for some ancient plants which were said to be protected from competition with recent migrants since the Eocene, because of their adaptation to ultramafic substrata brought by the ophiolitic obduction (see Morat et al., 1986 or Lowry, 1998 for reviews).

As a matter of fact, the geographic situation of New Caledonia is ideal for testing this hypothesis of relictness. This geologically old island is situated together with New Zealand on the Norfolk Ridge which 
culminate between two deep oceanic basins (minimum depth of $2000 \mathrm{~m}$ ). Therefore, in spite of sea level variations, it has been totally isolated from Australia, Vanuatu Islands, and even from the small volcanic Loyalty or Lord Howe Islands which appeared, respectively, $2 \mathrm{Myr}$ and 7-8 Myr ago on other ridges. Indeed, even the partial connection of New Caledonia with New Zealand, which has sometimes been assumed through a series of volcanic islands located along the Norfolk ridge, remained speculative since the Norfolk ridge was mostly too deep to have emerged (Paris, 1981).

In this context, the local origin of biodiversity, with such high richness and endemism can be questioned, as has already been done for New Zealand (Cooper and Cooper, 1995; Trewick, 2000; Pole, 2001). Does it result from the local and progressive diversification of ancient lineages since Gondwanan times or has it been shaped by recent diversifications and/or possible long-distance dispersals (e.g., Swenson et al., 2001)? This question has not been answered for New Caledonia using modern phylogenetic methodology, although this island is an ideal site to distinguish between paleoendemics and neoendemics. What we do know is that the New Caledonia has been totally isolated and large since long ago, its climate has remained stable and tropical, and it has experienced major geological changes.

The present study is aimed at answering the question of the age of New Caledonian local endemism at a specific level using a molecular phylogenetic study of a clade of insects belonging to the dictyopteran subfamily Tryonicinae, distributed both in Australia and in New Caledonia, specifically the cockroach genus Angustonicus Grandcolas (1997). This study utilized representatives from New Caledonia itself and from neighboring recent reefal islands. Both the biogeography and the molecular data should allow us to date the origin of the cladogenesis in this group and its subsequent diversification.

\section{Materials and methods}

\section{Collection of samples}

Nine of the 10 known species of the New Caledonian genus Angustonicus (Grandcolas, 1997; Pellens, 2004) were used in this study. The remaining species is known only from an old type specimen not available for DNA extraction and sequencing. Two other Tryonicinae (Lauraesilpha maeretoi and Rothisilpha najtae) were added as outgroups. Vouchers for all specimens were deposited at the Muséum national d'Histoire naturelle (MNHN) in Paris, and form part of the typical series mentioned in Grandcolas (1997) and in Pellens (2004). Many forest locations were visited, some of which harbored Angustonicus species (Appendix 1). New Zealand and New Guinea faunas are presently not known to comprise any Tryonicinae cockroaches (Johns, 1966; Grandcolas, 1997).

\section{DNA extraction, amplification and sequencing}

Partial sequences of two mitochondrial ribosomal genes, 12S and 16S rRNA, equivalent to some already reported (Kambhampati, 1996; Grandcolas, 2002) were sequenced. Genomic DNA was extracted from the leg musculature of dried specimens. Tissues were homogenized in $100 \mu \mathrm{L}$ of buffer $(10 \mathrm{~mm}$ Tris- $\mathrm{HCl} \mathrm{pH} 9,0.1$ EDTA, $1 \%$ SDS and proteinase $\mathrm{k} 0.2 \mathrm{mg} / \mathrm{mL}$ ) with a sterile plastic pestle. The homogenate was incubated for $4 \mathrm{~h}$ at $55^{\circ} \mathrm{C}$, and the DNA was precipitated with a phenol-chloroform method, the genomic DNA was then resuspended in TE buffer $(\mathrm{pH} 8)$. A polymerase chain reaction was carried out in a thermal cycler (MJ Research Inc.) using EcoTaq polymerase (Ecogen). PCR conditions were: $94{ }^{\circ} \mathrm{C}$ for 3 min followed by 35 cycles of $94{ }^{\circ} \mathrm{C}$ for $30 \mathrm{~s}, 51{ }^{\circ} \mathrm{C}$ for $1 \mathrm{~min}, 72{ }^{\circ} \mathrm{C}$ for $1.5 \mathrm{~min}$, and finally an extension period of $72{ }^{\circ} \mathrm{C}$ for $5 \mathrm{~min}$. The amplified product was electrophoresed on a $1.2 \%$ agarose gel. PCR-amplified DNA fragments were cloned into a psTblue vector (Novagen). the Clones were sequenced on both strands in an ABI (Perkin Elmer) automated fluorescence sequencing system.

Published primers (Kambhampati, 1995; Kambhampati, 1996) were used to amplify a fragment of $12 \mathrm{~S}$ rRNA ( $\sim 430 \mathrm{bp})$ and 16S rRNA ( 410 bp). The sequences have been deposited in the EMBL Nucleotide Sequence Database under accession numbers AJ308735, AJ308734 and AJ870989 to AJ871007 for $12 \mathrm{~S}$ and 16S. A. pouebo has been successfully sequenced only for $16 \mathrm{~S}$. Analyses have been carried out with or without this species to check that the lack of $12 \mathrm{~S}$ data do not change the results.

\section{Phylogenetic analysis}

Because the sequence length varies among species in ribosomal genes, alignment can remain ambiguous. In that perspective, Direct Optimization (Wheeler, 1996) implemented in the computer program POY (Wheeler, et al. 1996-2003) was used to analyze the data. For the parsimony analysis, 1000 replicates were conducted using random addition sequences and submitted to TBR branch swapping and ratcheting (Nixon, 1999). The influence of indel cost was studied in a sensitivity analysis framework (Wheeler, 1995). The ratio of weights between indels and substitutions ranged from 0.5 to 4 , resulting in four parameter sets (indel transversion transition): 122, 111 (equal weighting), 211 and 411 . We considered the tree whose parameter set maximized the congruence among the partitions, corresponding to the lowest ILD metrics (Mickevich and Farris, 1981). This method provides an objective criterion for choosing among the parameter sets. Bremer support (Bremer, 1988) and 
Symmetric Resampling frequencies (Goloboff et al., 2003) were calculated, as well as Geometric mean length (Grandcolas et al., 2004) for Acctran branch optimizations. Symmetric Resampling frequencies were calculated with TNT (Goloboff et al., 2004).

\section{Dating}

To explore the rate of diversification within the genus Angustonicus in New Caledonia, we compared estimates from two methods. Paleogeographic criteria (dates of emergence of neighboring reefal islands harboring Angustonicus species) were employed because the geology of the New Caledonian region has been extensively studied (Dubois et al., 1974; Paris, 1981). We also used the rates of molecular divergence with reference to the classical nucleotide substitution rates found in the literature for mitochondrial genes (Brower, 1994; Sperling, 1997). This second method, as with all molecular clocks, is obviously speculative and we only intend to check how much its results are consistent with the first one. Uncorrected pairwise sequence divergences have been calculated using PAUP* 4.0b10 (Swofford, 2003). The phylogenetic sensitivity analysis permitted us to check whether the dates remained stable with different sequence alignments.

\section{Results}

As a whole, the genus Angustonicus is widely distributed across New Caledonia, even if it was not found in some large mountains or forested areas (e.g., Mont Panié, Massif de l'Aoupinié, Fig. 1). Angustonicus species proved to be short range endemics, since all species were captured in very localized sites (contrast Fig. 1 and Appendix 1).

The tree shown (Fig. 1) results from the optimal parameter set 211 (the best congruence among data partitions, $\mathrm{ILD}_{211}=0.00209$ ), obtained by parsimony analysis under direct optimization (479 steps, $\mathrm{CI}=0.47$; $\mathrm{RI}=0.85 ; \mathrm{RGML}=59 \%=15 / 25.2$ ). In the monophyletic genus Angustonicus, the clade formed by two species from the Loyalty Islands is a sister-group of the remainder of the clade comprising only species from the main New Caledonia island ("Grande Terre"). The species of Grande Terre are related to each other along a geographic cline, from the more basal Northern species, to the more apical Southern ones. Using the parameter set 111 (the second best congruence among data partitions) did not change the main topology, but only altered the relationships of $A$. boucheti and $A$. koghensis which were found to be sister groups.

Substitution rates for the $12 \mathrm{~S}$ and $16 \mathrm{~S}$ ribosomal genes (Brower, 1994; Sperling, 1997) gave a range of dates from 1.32 to $3.97 \mathrm{Myr}$ for the node supporting the sister group relationships between Loyalty Islands and Grande Terre. The node between $A$. yate and A. pinorum has a range of 1.28-0.43 Myr (Fig. 1). Paleogeographic data (Dubois et al., 1974; Paris, 1981) provided a maximum age of $2 \mathrm{Myr}$ for any node concerning species from reefal islands. These dates appear very congruent from paleogeographic or molecular data, and derived

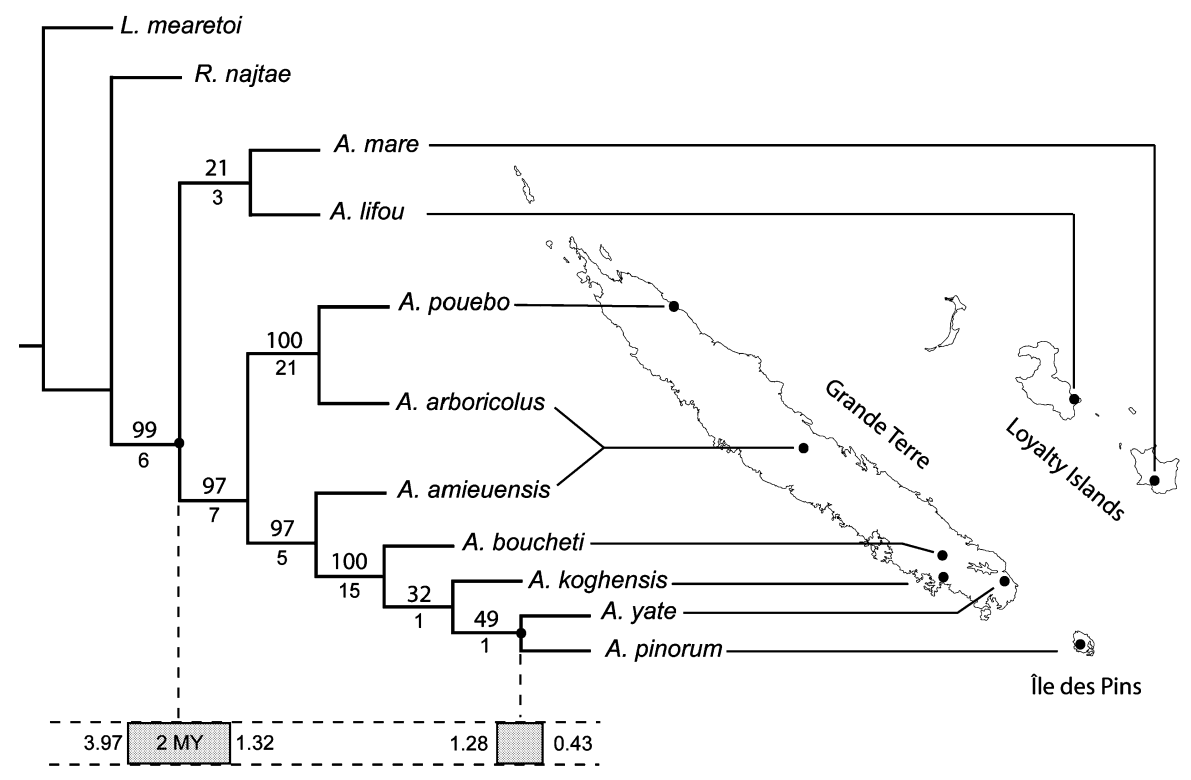

Fig. 1. Cladogram of the genus Angustonicus in New Caledonia mainland and adjacent islands (Loyalty Islands at the East, and Île des Pins in the South), based on direct optimization analyses of portions of $12 \mathrm{~S}$ and $16 \mathrm{~S}$ mitochondrial genes (parameter set: 211,479 steps, CI $=0.47$; RI $=0.85$; RGML $=59 \%=15 / 25.2$ ). The numbers on the branches are Symmetric Resampling frequencies (above) and Bremer index (below) values. Basal diversification of the clade in New Caledonia mainland is not older than $2 \mathrm{Myr}$, according to paleogeographic (central number) and molecular datings (grey range with marginal values). Dispersal to Île des Pins is dated around 1 Myr. 
from a topology insensitive to alignment parameters and supported by high Bremer and Symmetric Resampling values.

\section{Discussion}

The main purpose of this work was to understand whether the specific endemism and richness of the New Caledonian biota could be necessarily dated back to Gondwanan times. This widely held hypothesis is believed to explain the species richness and biodiversity in this hotspot: the New Caledonian species would then be the result of local and progressive diversification from direct descendants of Gondwanan organisms, in spite of the major Tertiary geological disturbances occurring on this island, Paleocene submersion, and Eocene ophiolitic obduction (Paris, 1981; Brothers and Lillie, 1988; Cluzel et al., 2001; Lee et al., 2001). This assertion is considered especially likely in the literature when the organisms under consideration are endemic and belong to the so-called Gondwanan groups restricted to Austral territories.

Such an assertion of old endemism and richness is not corroborated by our study on the diversification of the genus Angustonicus. This cockroach genus is endemic to New Caledonia and belongs to a Gondwaniandistributed group of insects (Grandcolas, 1997). However, its diversification (not its origin) in New Caledonia cannot be dated to earlier than the emergence of the Loyalty islands where the basal members of the clade occur, i.e. no earlier than $2 \mathrm{Myr}$ (Dubois et al., 1974; Paris, 1981; Cabioch, 2003). This convincing paleogeographic date is in agreement with results obtained by the molecular clock approach. Both methods provide a clear and unambiguous date for the New Caledonian diversification as a recent process, occurring not before the end of Pliocene.

This highly supported scenario also implies that the genus has diversified in the Loyalty Islands by dispersal from the New Caledonia mainland, since all other members of the subfamily Tryonicinae are only found on the New Caledonia mainland or Australia. Indeed, Angustonicus lifou and A. mare are the only Tryonicinae species in the Loyalty Islands. From strong geological and bathymetric data, including isotopic dating (Dubois et al., 1974; Paris, 1981; Cabioch, 2003), it is clear that the New Caledonian and Loyalty Islands were isolated from each other, even during important Pliocene sea level variations. Dispersal in this case is unambiguously indicated by both phylogenetic and geological data and is not an ad hoc hypothesis brought forward to propose a biogeographically conventional story.

In addition, the phylogeny of the genus Angustonicus in New Caledonia shows a clinal trend among mainland taxa, with basal species in the northern part of the mainland and more apical ones in the southern part and Île des Pins (Fig. 1). Such clinal patterns in New Caledonia have sometimes been hypothesized to be caused by a progressive recolonization of the mainland with ultramafic substrate after the Eocene south-eastern ophiolitic obduction (Paris, 1981; Morat et al., 1986). This geological hypothesis invoking Eocene events (50 Myr) is completely at odds with our recent dating for Angustonicus diversification (2 Myr). The clinal diversification could rather be related to the orogenesis and the peneplanation, which are very recent and asymmetrical events in the New Caledonia mainland (Paris, 1981), as for similar endemism in New Zealand (Trewick et al., 2000; Chinn and Gemmell, 2004).

This clinal trend also includes the species $A$. pinorum from the Île des Pins, the very apical position of which suggests that this trend resulted from colonization and "progression" southward. The Île des Pins has undergone the same and contemporaneous uplift as Loyalty Islands and some south-eastern parts of the mainland 2 Myr ago (Dubois et al., 1974; Paris, 1981; Cabioch, 2003). However, according to the phylogeny, it has necessarily been colonized later. Therefore, the whole set of events concerning the Angustonicus diversification could have been: first colonizing the Loyalty Islands a maximum of $2 \mathrm{Myr}$ ago from the New Caledonian mainland, then progressing southward on the mainland, and colonizing the Île des Pins as a final step.

Since the diversification occurred very recently, one can consider that the geographic ranges of the distribution of the species have not changed from the time of speciation to the present day (Losos and Glor, 2003). According to the ranges of species areas, only allopatric speciation took place, which corroborates the hypothesis of environmental causes for speciation instead of intrinsic causes.

Even if this group radiated very recently, we cannot infer with certainty from the present study if the group was present on the island earlier or only recently. The recent diversification of Angustonicus within the Australian-Neocaledonian subfamily Tryonicinae is however, consistent with an autochthonous Gondwanan group submitted to Paleocene or Eocene bottlenecks during Tertiary submersion or obduction. One can also make the hypothesis that Tertiary catastrophic events have caused a total extinction in New Caledonia and that recolonization has occurred later, by dispersal. The hypothetical presence of temporary "stepping stone" islands on an oceanic ridge has been invoked to explain that type of situation (Lee et al., 2001), but we found no clear relevant geological evidence for them in the literature.

In conclusion, far from being a relict Gondwanan territory which has remained unchanged over $85 \mathrm{Myr}$, New Caledonia appears to be a shaky piece of Gondwana, with several Tertiary catastrophic periods 
involving possible mass extinctions and recent diversifications.

\section{Acknowledgments}

We are grateful to Greg Edgecombe, Philippe Bouchet, two anonymous referees and James Carpenter who commented on this manuscript and to those who commented on the presentation of the study at the XXIII Hennig meeting in Paris. This work has been carried out with a grant from the MNHN pluriformations programme "Biodiversité Terrestre en Nouvelle Calédonie", under the supervision of Judith Najt with two field trips in 1994 and in 1996, and also with a Picasso grant from the Ministère des Affaires Étrangères (1998-99), to both the CSIC team in Barcelona and the CNRS team in Paris. We thank the following persons and institutions who have made our field work possible: P. Bouchet (MNHN), R. Boulet (Service de l'Environnement et de la Gestion des Parcs et Réserves, Nouméa), J. Chazeau (IRD, Nouméa), L. Desutter-Grandcolas (MNHN), T. Jaffré (IRD, Nouméa), C. Latreille (Direction du Développement Rural et de la Pêche, Poindimié), J.-M. Veillon (IRD, Nouméa).

\section{References}

Bremer, K., 1988. The limits of amino acid sequence data in angiosperm phylogenetic reconstruction. Evolution, 42, 795-803.

Brothers, R.N., Lillie, A.R., 1988. Regional geology of New Caledonia. The ocean basins and margins. In: Nairn, A.E.M., Stehli, F.G., Uyeda, S. (Eds.), The Pacific Ocean, Vol. 7B. Plenum Press, New York, pp. 325-374.

Brower, A.V.Z., 1994. Rapid morphological radiation and convergence between races of the butterfly Heliconius erato inferred from patterns of mitochondrial DNA evolution. Proc. Natl Acad. Sci. USA, 91, 6491-6495.

Cabioch, G., 2003. Postglacial reef development in the South-West Pacific: case studies from New Caledonia and Vanuatu. Sediment. Geol. 159, 43-59.

Chazeau, J., 1993. Research on New Caledonian terrestrial fauna: achievements and prospects. Biodiv. Lett. 1, 123-129.

Chinn, W.G., Gemmell, N.L., 2004. Adaptative radiation within New Zealand endemic species of the cockroach genus Celatoblatta Johns (Blattidae): a response to Plio-Pleistocene mountain building and climate change. Mol. Ecol. 13, 1507-1518.

Cluzel, D., Aitchison, J.C., Picard, C., 2001. Tectonic accretion and underplating of mafic terranes in the Late Eocene intraoceanic fore-arc of New Caledonia (Southwest Pacific): geodynamic implications. Tectonophysics, 340, 23-59.

Cooper, A., Cooper, R.A., 1995. The Oligocene bottleneck and New Zealand biota: genetic record of a past environmental crisis. Proc. R. Soc. Lond. B 261, 293-302.

Cooper, R.A., Millener, P.R., 1993. The New Zealand biota: historical background and new research. Trends Ecol. Evol. 8, 429-433.

Daugherty, C.H., Gibbs, G.W., Hitchmough, R.A., 1993. Mega-island or micro-continent? New Zealand and its fauna. Trends Ecol. Evol. $8,437-442$.
Dubois, J., Launay, J., Recy, J., 1974. Uplift movements in New Caledonia-Loyalty Islands area and their plate tectonics interpretation. Tectonophysics, 24, 133-150.

Fleischer, R.C., McIntosh, C.E., Tarr, C.L., 1998. Evolution on a volcanic conveyor belt: using phylogeographic reconstructions and $\mathrm{K}$-Ar-based ages of the Hawaiian Islands to estimate molecular evolutionary rates. Mol. Ecol. 7, 533-545.

Gillespie, R.G., Roderick, G.K., 2002. Arthropods on islands: colanisation, speciation, and conservation. Ann. Rev. Entomol. 47, 595-632.

Goloboff, P.A., Farris, J.S., Källersjö, M., Oxelman, B., Ramírez, M.J., Szumik, C.A., 2003. Improvements to resampling measures of group support. Cladistics, 19, 324-332.

Goloboff, P.A., Farris, J.S., Nixon, K., 2004. TNT (Tree Analysis Using New Technology), Version 1. Published by the authors, Tucumán, Argentina.

Grandcolas, P., 1997. Systématique phylogénétique de la sous-famille des Tryonicinae (Dictyoptera, Blattaria, Blattidae). In: Najt, J., Matile, L. (Eds.), Zoologia Neocaledonica 4, Mém. Mus. Natl Hist. nat. 171, 91-124.

Grandcolas, P., 2002. Le genre Lauraesilpha Grandcolas, 1997. nouvelles espèces, endémisme, séquences d'ARN ribosomique et caractères d'appartenance au Blattidae (Insectes, Dictyoptères, Blattidae, Tryonicinae). In: Najt, J., Grandcolas, P. (Eds.), Zoologia Neocaledonica. 5. Systématique et endémisme en Nouvelle-Calédonie. Mém. Mus. Natl Hist. nat. 187, 117-131.

Grandcolas, P., Robillard, T., D'Haese, C., Desutter-Grandcolas, L., Guilbert, E., Murienne, J., 2004. The geometric mean length, a new statistic to describe the distribution of character steps on a tree. Cladistics, 20, 219-222.

Grant, P.R., 1986. Ecology and Evolution of Darwin's Finches. Princeton University Press, Princeton.

Johns, P.M., 1966. The cockroaches of New Zealand. Rec. Canterbury Mus. 8, 93-136.

Kambhampati, S., 1995. A phylogeny of cockroaches and related insects based on DNA sequence of mitochondrial ribosomal RNA genes. Proc. Natl Acad. Sci. USA, 92, 2017-2020.

Kambhampati, S., 1996. Phylogenetic relationship among cockroach families inferred from mitochondrial $12 \mathrm{~S}$ rRNA gene sequence. Syst. Entomol. 21, 89-98.

Lee, D.E., Lee, W.G., Mortimer, N., 2001. Where and why have all the flowers gone? Depletion and turnover in the New Zealand Cenozoic angiosperm flora in relation to paleogeography and climate. Aust. J. Bot. 49, 341-356.

Losos, J.B., Glor, R.E., 2003. Phylogenetic comparative methods and the geography of speciation. Trends Ecol. Evol. 18, 220-227.

Lowry, P.P., 1998. Diversity, endemism, and extinction in the flora of New Caledonia: a review. In: Peng, C.I., Lowry, P.P. (Eds.), Proceedings of the International Symposium on Rare, Threatened, and Endangered Floras of Asia and the Pacific. Institute of Botany, Academica Sinica, Monogr. Ser. no. 16, Taipei, Taiwan, pp. 181206.

Mickevich, M.F., Farris, J.S., 1981. The implications of congruence in Menidia. Syst. Zool. 27, 143-158.

Morat, P., 1993. Our knowledge of the flora of New Caledonia. endemism and diversity in relation to vegetation types and substrates. Biodiv. Lett. 1, 72-81.

Morat, P., Veillon, J.-M., MacKee, H.S., 1986. Floristic relationships of New Caledonian rainforest phanerogams. Telopea, 2, 631-679.

Myers, N., Mittermeier, R.A., Mittermeier, C.G., da Fonseca, G.A.B., Kent, J., 2000. Biodiversity hotspots for conservation priorities. Nature, 403, 853-858.

Najt, J., Grandcolas, P. (Eds.), 2002. Zoologica Neocaledonica, 5. Systématique et endémisme en Nouvelle Calédonie. Mém. Mus. natl Hist. nat. 187, 1-282.

Nixon, K.C., 1999. The parsimony ratchet, a new method for rapid parsimony analysis. Cladistics, 15, 407-414. 
Paris, J.P., 1981. Géologie. In: Atlas de la Nouvelle Calédonie et Dépendances. Editions de l'Office de la Recherche Scientifique et Technique Outre-Mer, Paris, Pl. 9.

Parkinson, C.L., Adams, K.L., Palmer, J.D., 1999. Multigene analyses identify the three earliest lineages of extant flowering plants. Curr. Biol. 9, 1485-1488.

Pellens, R., 2004. Nouvelles espèces d'Angustonicus (Insecta, Dictyoptera, Blattaria, Tryonicinae) et endémisme du genre en NouvelleCalédonie. Zoosystema, 26, 307-314.

Pole, M.S., 2001. Can long-distance dispersal be inferred from the New Zealand plant fossil record? Aust. J. Bot. 49, 357-366.

Raven, P.H., 1979. Plates tectonics and southern hemisphere biogeography. In: Larsen, K., Holm-Nielsen, L.B. (Eds.), Tropical Botany. Academic Press, London, pp. 3-24.

Sperling, F.A.H., 1997. Mitochondrial DNA, allozymes, morphology, and hybrid compatibility in Limnoporus water striders (Heteroptera: Gerridae): do they all track species phylogenies? Ann. Entomol. Soc. Am. 90, 401-415.

Swenson, U., Backlund, A., McLoughlin, S., Hill, R.S., 2001. Nothofagus biogeography revisited with special emphasis on the enigmatic distribution of subgenus Brassospora in New Caledonia. Cladistics, 17, 28-47.

Swofford, D.L., 2003. PAUP*. Phylogenetic Analysis Using Parsimony (*and Other Methods), Version 4. Sinauer Associates, Sunderland, MA.

Trewick, S.A., 2000. Molecular evidence for dispersal rather than vicariance as the origin of flightless insect species on the Chatham Islands, New Zealand. J. Biogeogr. 27, 1189-1200.

Trewick, S.A., Wallis, G.P., Morgan-Richards, M., 2000. Phylogeographical pattern correlates with Pliocene mountain building in the alpine scree weta (Orthoptera, Anostostomatidae). Mol. Ecol. 9, 657-666.

Wagner, W.L., Funk, V.A., 1995. Hawaiian Biogeography: Evolution on a Hot Spot Archipelago. Smithsonian Institution Press, Washington, DC.

Wheeler, W.C., 1995. Sequence alignment, parameter sensitivity and the phylogenetic analysis of molecular data. Syst. Biol. 44, 321-331.

Wheeler, W.C., 1996. Optimization alignment: the end of multiple sequence alignments in phylogenetics? Cladistics, 12, 1-9.

Wheeler, W.C., Gladstein, D.S., De Laet, J., 1996-2003. POY, Version 3.0. ftp://ftp.amnh.org/pub/molecular/poy (current version 3.0.11). Documentation by Daniel Janies and Ward Wheeler. Commandline documentation by J. De Laet and. W.C. Wheeler.

\section{Appendix 1}

List of the study sites in New Caledonia and neighboring islands where Angustonicus spp. has been searched for (and found *).

Adio (forest and caves) $21^{\circ} 32^{\prime} \mathrm{S}, 165^{\circ} 17^{\prime} \mathrm{E}$

Aoupinié (13 km S.W. Ponérihouen) $21^{\circ} 18^{\prime} \mathrm{S}$, $165^{\circ} 25^{\prime} \mathrm{E}$

Bourail $21^{\circ} 57^{\prime} \mathrm{S}, 165^{\circ} 48^{\prime} \mathrm{E}$

*Col d'Amieu (3 km NW) 21 $61^{\prime} \mathrm{S}, 166^{\circ} 75^{\prime} \mathrm{E}$

Col d'Amieu $21^{\circ} 61^{\prime} \mathrm{S}, 166^{\circ} 75^{\prime} \mathrm{E}$

Col d'Amieu (Pic Vincent) $21^{\circ} 61^{\prime} \mathrm{S}, 166^{\circ} 75^{\prime} \mathrm{E}$

Galarino $20^{\circ} 29^{\prime} 46.4^{\prime \prime} \mathrm{S}, 164^{\circ} 45^{\prime} 25.3^{\prime \prime} \mathrm{E}$

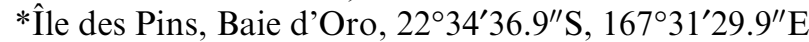

Île des Pins, Baie Waa Më, $22^{\circ} 35^{\prime} 24.6^{\prime \prime} \mathrm{S}$, $167^{\circ} 25^{\prime} 30.8^{\prime \prime} \mathrm{E}$

Lifou (Loyalty Island, Wedrumel) $20^{\circ} 98^{\prime} \mathrm{S}, 167^{\circ} 11^{\prime} \mathrm{E}$

*Lifou (Loyalty Island, Cap des Pins) $21^{\circ} 03^{\prime} \mathrm{S}$, $167^{\circ} 41^{\prime} \mathrm{E}$

*Maré (Loyalty Island) $21^{\circ} 59^{\prime} \mathrm{S}, 167^{\circ} 87^{\prime} \mathrm{E}$

*Mé Aréto (mountain close to Col d'Amieu), $21^{\circ} 36^{\prime} 14.8^{\prime \prime} \mathrm{S}, 165^{\circ} 46^{\prime} 26.6^{\prime \prime} \mathrm{E}$

Mont Do $21^{\circ} 73^{\prime} \mathrm{S}, 166^{\circ} 00^{\prime} \mathrm{E}$

*Monts Koghis (basis) $22^{\circ} 16^{\prime} \mathrm{S}, 166^{\circ} 49^{\prime} \mathrm{E}$

Mont Mou (summit) $22^{\circ} 04^{\prime} 34.23^{\prime \prime} \mathrm{S}, 166^{\circ} 20^{\prime} 9.9^{\prime \prime} \mathrm{E}$

Mont Panié (basis) $20^{\circ} 33^{\prime} 16^{\prime \prime} \mathrm{S}, 164^{\circ} 47^{\prime} 36^{\prime \prime} \mathrm{E}$

Mont Panié (summit) $20^{\circ} 60^{\prime} \mathrm{S}, 167^{\circ} 75^{\prime} \mathrm{E}$

Ouen Toro (Nouméa) $22^{\circ} 32^{\prime} \mathrm{S}, 166^{\circ} 42^{\prime} \mathrm{E}$

Pindaï (sclerophyllous forest) $21^{\circ} 34^{\prime} \mathrm{S}, 166^{\circ} 88^{\prime} \mathrm{E}$

Plateau de Dogny, $21^{\circ} 37^{\prime} 9.5^{\prime \prime} \mathrm{S}, 165^{\circ} 52^{\prime} 28.8^{\prime \prime} \mathrm{E}$

*Port Boisé (Yaté, Goro), $22^{\circ} 18^{\prime} 1.3^{\prime \prime} \mathrm{S}, 167^{\circ} 00^{\prime} 50.5^{\prime \prime} \mathrm{E}$

Port Boisé (Yaté, Wharf), 22²0'53.1"S, $166^{\circ} 57^{\prime} 50.5^{\prime \prime} \mathrm{E}$

*Pouébo $20^{\circ} 40^{\prime} \mathrm{S}, 164^{\circ} 57^{\prime} \mathrm{E}$

Poum $20^{\circ} 29^{\prime} 46.4^{\prime \prime} \mathrm{S}, 164^{\circ} 01^{\prime} 28.3^{\prime \prime} \mathrm{E}$

*Rivière bleue ( $25 \mathrm{~km}$ N.E. Nouméa)

Sarraméa $21^{\circ} 65^{\prime} \mathrm{S}, 165^{\circ} 85^{\prime} \mathrm{E}$

Table Unio (basis), $21^{\circ} 34^{\prime} 10.2^{\prime \prime} \mathrm{S}, 165^{\circ} 46^{\prime} 15^{\prime \prime} \mathrm{E}$

*Table Unio (summit), $21^{\circ} 33^{\prime} 56.5^{\prime \prime} \mathrm{S}, 165^{\circ} 46^{\prime} 15^{\prime \prime} \mathrm{E}$

Vallé de la Thi $22^{\circ} 22^{\prime} \mathrm{S}, 166^{\circ} 51^{\prime} \mathrm{E}$

Yaté $22^{\circ} 15^{\prime} \mathrm{S}, 166^{\circ} 90^{\prime} \mathrm{E}$ 